\title{
Development of HospitalQual: A Service Quality Scale for Measuring In-patient Services in Hospital
}

\author{
Ramaiah Itumalla \\ School of Management Studies, \\ University of Hyderabad, Hyderabad, Telangana State, India \\ Email: ramauhealthcare@gmail.com \\ G.V.R.K Acharyulu \\ School of Management Studies, \\ University of Hyderabad, Hyderabad, Telangana State, India \\ Email: acharyulu_gvrk@yahoo.com (Corresponding Author)
}

\author{
B. Raja Shekhar \\ School of Management Studies, \\ University of Hyderabad, Hyderabad, Telangana State, India \\ Email: brsmsuh@gmail.com
}

\begin{abstract}
Service quality has become a major concern for both the hospitals and the patients. The increase in competition coupled with the increased patients' perception of service quality makes it difficult for hospitals to provide services that meet patient satisfaction. Recognition of the importance of service quality is the need of the hour in order to provide better services to the patients. The objectives of the present study are to identify the critical factors of inpatient service quality in a hospital and to develop the HospitalQual theoretical model to measure inpatient service quality. The present study was explorative and descriptive in its nature. An empirical study was conducted in a public hospital located in Hyderabad, India. The data was collected through a self administered questionnaire from 246 in-patients with a purposive sampling technique. The statistical techniques such as factor analysis and the multiple regression were used in the data analysis. The study has identified the factors to measure the inpatient service quality and developed a comprehensive instrument i.e. "HospitalQual" with seven dimensions, namely; medical, nursing, support, administrative services, patient safety, communication and hospital infrastructure. In addition, the supportive services are found to be the most important factor to predict the overall inpatient service quality, followed by nursing services, administrative services, medical services, patient communication patient safety and hospital infrastructure. The application of HospitalQual would help to identify the gaps in each of the dimensions over a period of time and enable hospital administrators to monitor, control and improve the inpatient service quality in a hospital.
\end{abstract}

Keywords: hospital, hospitalqual, service quality

\section{INTRODUCTION}

Service quality has become a major concern for both the hospitals and the patients. Hospital today is very different from what it was a couple of decades ago. The increase in competition coupled with the increased patients' perception of service quality makes it difficult for hospitals to provide services that meet patient satisfaction. Recognition of the importance of service quality is the need of the hour in order to provide better services to the patients. Identification of the determinants of service quality is one of the burning issues before services research (Johnston, 1995). The identification of determinants of service quality is necessary in order to measure, control, and improve customer perceived service quality.

The healthcare industry has viewed itself as operates differently from other industry (Kritchanchai, D., 2012). In the globalized competitive hospital environment, service quality has been increasingly identified as the main factor in distinguishing between services and building competitive advantage. Unlike in the earlier days when hospitals were judged by the medical services they provided, they are now also judged on the quality of service they give, that is, personalized services rendered by courteous, caring and friendly staff. Hospitals will do even better if they could possibly combine high tech with a high touch. Service quality is designed to measure functional quality i.e. the manner in which the health care service is delivered to the patient. However, functional quality in a health care setting cannot be sustained without accurate diagnoses and procedures. Such technical quality is the focus of research that is being conducted by a number of healthcare professional organizations, including Joint Commission International (JCI), National Accreditation Board for Hospitals \& Health care Providers (NABH) and Quality Council of India (QCI) etc. For the long-run success of a health care organization, both functional and technical quality have to be monitored and managed effectively (Babakus Emin \& W Glynn Mangold, 1992). Hence, the need to focus on the management aspects of hospitals has become more relevant than before. Measuring service quality as perceived by patients is one step to improve management of the hospitals. In this context, it is very 
essential to study the service quality in Indian hospitals. The present study is an attempt to develop an instrument for measuring perceived in-patent service quality in the context of Indian hospitals.

\section{SERVICE QUALITY}

The well-documented service quality model i.e. SERVQUAL of Parasuraman et al. (1985) has been created a revolution in measuring the customers' perceptions towards the service delivered by the provider in various service sectors. Along with all service sectors, the model is also widely used for measuring service quality in health care including hospitals. According to SERVQUAL model, service quality occurs when expectations are met (or exceeded) and a service gap materializes if expectations are not met (Parasuraman et al., 1985). The gap score for each statement is calculated as the perception score minus the expectation score. A positive gap score implies that expectations have been met or exceeded and a negative score implies that expectations are not being met. Gap scores can be analyzed for individual statements and can be aggregated to give an overall gap score for each dimension.

Early studies during 1980s concentrated on determining what service quality meant for customers and developing strategies to meet customer expectations (Parasuraman 1985). The early pioneers of services marketing in Europe, especially the Nordic School, argued that service quality consists of two or three underlying dimensions. Lehtinen and Lehtinen (1985) referred to physical and interactive quality while Gro"nroos (1984) identified the dimensions such as technical, functional and firm's image. Building on the pioneering work of the Nordic School of services management and particularly Christian Gronroos, Parasuraman et. al. established service quality as the core of services marketing. Their landmark article in 1985 conceptualized service quality as a gap between consumers' expectations and perceptions (Parasuraman et al., 1985) and inspired many other researchers to examine the service quality construct within a marketing premise (Berry et al., 1985). In later years, Parasuraman et al. (1988) published empirical evidence from five service industries that suggested that five dimensions more appropriately capture the perceived service quality construct.

\section{SERVICE QUALITY DIMENSIONS IN HOSPITAL - A REVIEW}

Ever since the development of Parasuraman's SERVQUAL, the researchers continue to debate the determinants of service quality which is still an important issue remain unanswered. Practitioners continue to look for advice and suggestion as to what constitute service quality for their offers and furthermore, if they tend to reposition their offers by varying some characteristics of their offers, for example, by increasing or reducing tangibility or customer contact, etc. (Nimit Chowdhary, Monika Prakash, 2007). However, it is essential to examine the factors influencing the service quality (Zakaria, H. et al, 2010).

The application of SERVQUAL has been widely used in hospital to measure the service quality. Some of the researchers have modified the SERVQUAL dimensions, whereas the others have been developing the new service quality dimensions to fit their study. Lim and Tang (2000) added the dimensions such as accessibility/affordability and Tucker and Adams (2001) also added caring and outcome dimensions. Johnston (1995), has increased SERVQUAL model to 18 dimensions, whereas Reidenbach and SandiferSmallwood (1990) differed with Johnston and they reduced to seven dimensions; patient confidence, empathy, quality of treatment, waiting time, physical appearance, support services and business aspects.

Apart from these additions and deletions in the detentions of service quality by various scholars, there is an another group of scholars those who have derived measurement scales with an attempt to quantify the quality of service provided by a hospital (Hulka et al., 1970; and Fitzpatrick, 1991). Hulka et al. (1970) used statements based on just three dimensions: personal relationship, convenience, and professional competence. Thompson (1983) based his work on seven dimensions: tangible, communications, relationships between staff and patients, waiting time, admission and discharge procedures, visiting procedures, and religious needs while Baker (1990) concentrated on consultation time, professional care, and depth of relationship. Other researchers, Tomes and $\mathrm{Ng}$ (1995) conducted content analysis with a total of eight dimensions and renamed the dimension as empathy, understanding of illness, relationship of mutual respect, dignity, food, physical environment, and religious needs.

Camilleri and O'Callaghan (1998) consider the professional and technical care, service personalization, price, environment, patient amenities, accessibility and, catering as suitable dimensions in measuring hospital service quality. Andaleeb (1998) on the other hand, limits his set of variables to only five dimensions: communication, cost, facility, competence, and demeanor. Jun et al. (1998), conducted focus group interviews, identifies the 11 dimensions such as tangibles, courtesy, reliability, communication, competence, understanding customer, access responsiveness, caring, patient outcomes, and collaboration. Five dimensions identified by Hasin et al. (2001) which includes communication, responsiveness, courtesy, cost, and cleanliness. Yet, Walters and Jones (2001) introduced elements, namely: security, performance, aesthetics, convenience, economy, and reliability to measure the service quality in hospital. John (1989) recommends four dimensions of health care service quality: curing, caring, access, and physical environment. Jabnoun and Chaker (2003) used the ten-dimensions: tangibles, accessibility, understanding, courtesy, reliability, security, credibility, responsiveness, communication, and competence. Further, Tracey S. Dagger et.al (2007) used interpersonal quality, technical quality, environment quality, and administrative quality; Huseyin Arasli et.al, (2008) used empathy, giving priority to the inpatients needs, relationships between staff and patients, professionalism of staff, food, and the physical environment; Jayesh P. Aagja, Renuka Garg, (2010) used admission, medical service, overall service, discharge process, and social responsibility and Panchapakesan Padma, et.al (2010) used infrastructure, personnel quality, process of clinical care, administrative procedures, safety indicators, hospital image, social responsibility, and 
trustworthiness of the hospital dimensions to study the service quality in hospital.

\section{RESEARCH GAP}

From the literature review the following gaps are identified:

- There are hardly studies concentrated on inpatient service quality in hospital.

- The construct of hospital service quality has different factors in different studies.

- The studies on service quality in the hospital done mostly adopting the SERVQUAL model.

- The majority of the studies has been done in the context of developed countries, which cannot be generalized to the Indian context. It has been contended that constructs of service quality that are developed in one culture might not be applicable in another culture (Kettinger et al., 1995; Karatepe et al., 2005).

\section{OBJECTIVES OF THE STUDY}

The objectives of the present study are:

1. To identify the critical factors of inpatient service quality in a hospital

2. To develop the HospitalQual theoretical model to measure inpatient service quality

\section{HYPOTHESES OF THE STUDY}

The following hypotheses are framed in the study: $\mathrm{H}_{1}$ : Medical Service has a significant effect on inpatient service quality

$\mathrm{H}_{2}$ : Nursing Services have a significant effect on inpatient service quality

$\mathrm{H}_{3}$ : Supportive Services have a significant effect on inpatient service quality

$\mathrm{H}_{4}$ : Administrative Services have a significant effect on inpatient service quality

$\mathrm{H}_{5}$ : Patient Safety has a significant effect on inpatient service quality

$\mathrm{H}_{6}$ : Patient Communication has a significant effect on inpatient service quality

$\mathrm{H}_{7}$ : Hospital Infrastructure has a significant effect on inpatient service quality

\section{RESEARCH METHODOLOGY}

The present study is explorative and descriptive in its nature. An empirical study was conducted in a public hospital located in Hyderabad, India. Since it became impossible to conduct the focused group discussion (FGDs) with the inpatients, the study initially conducted twenty indepth interviews to identify the variables of inpatient service quality. Apart from this, people from industry and academia were consulted and also utilized the existing literature in the process of identifying the variables of service quality. However, the inpatients' interviews were used as the focal point, because the study was intended to identify the service quality dimensions from the inpatient's perceptions. The study is adopted a purposive sample method and the data was collected from 246 inpatients through a self administered questionnaire.

\subsection{Sample and Sample Characteristics}

The respondents of the study were inpatients, those who were about to discharge after the stay of at least three days and above from the public hospital. The rationale for choosing the inpatients with this criterion is that those patients would have experienced all kinds of services provided by the hospital. The 300 questionnaires were administered to the inpatients in the general wards and rooms. The researcher explained the objectives of the study and instructions to respondents. As a result the response rate was $82 \%$ with the total valid sample standing at 246 . The sample characteristics are as shown in the Table 1.

Table 1 Sample Characteristics

\begin{tabular}{|c|c|c|c|c|c|c|c|}
\hline Variable & Classification & Frequency & $\begin{array}{l}\text { Percentage (\%) } \\
\text { (based on the } \\
\text { sample size of } \\
246 \text { ) }\end{array}$ & Variable & Classification & Frequency & $\begin{array}{c}\text { Percentage } \\
(\%) \\
\text { (based on the } \\
\text { sample size } \\
\text { of } 246)\end{array}$ \\
\hline \multirow{2}{*}{ Gender } & Female & 104 & 42.27 & \multirow{5}{*}{$\begin{array}{l}\text { Annuval } \\
\text { Income }\end{array}$} & $<1$ Lakh & 30 & 12.19 \\
\hline & Male & 142 & 57.72 & & 1-2 Lakh & 40 & 16.6 \\
\hline \multirow{5}{*}{ Age } & $<18$ & 12 & 4.87 & & 2-3 Lakh & 58 & 23.57 \\
\hline & $19-30$ & 60 & 24.39 & & 3-4 Lakh & 68 & 27.64 \\
\hline & 30 to 50 & 96 & 39.02 & & $>4$ Lakh & 50 & 20.32 \\
\hline & 50 to 70 & 68 & 27.64 & \multirow{10}{*}{$\begin{array}{l}\text { Disease } \\
\text { Profile of the } \\
\text { respondents }\end{array}$} & Cardiology & 48 & 19.51 \\
\hline & $>70$ & 10 & 4.06 & & $\begin{array}{l}\text { Cardio Thoracic } \\
\text { surgery }\end{array}$ & 32 & 13 \\
\hline \multirow{4}{*}{ Education } & Illitrates & 18 & 7.31 & & Nurology & 28 & 11.38 \\
\hline & Schooling & 60 & 24.39 & & Gastroenterology & 34 & 13.82 \\
\hline & Undergraduate & 75 & 30.48 & & Gynaecology & 12 & 4.87 \\
\hline & PG and above & 93 & 37.80 & & Urology & 15 & 6.09 \\
\hline \multirow{4}{*}{ Occupation } & Labour & 13 & 5.28 & & Nephrology & 10 & 4.06 \\
\hline & $\begin{array}{c}\text { Private } \\
\text { Employee }\end{array}$ & 103 & 41.86 & & Orthopedics & 23 & 9.34 \\
\hline & $\begin{array}{l}\text { Government } \\
\text { Employee }\end{array}$ & 58 & 23.57 & & Nuclear medicine & 8 & 3.25 \\
\hline & Business & 72 & 29.26 & & General medicine & 36 & 14.63 \\
\hline
\end{tabular}




\subsection{Sample Justification}

The study has followed the concept of "five subjects for one variable" suggested by Hair et al., (2008), for the determination of the total number of subjects in the sample of the explorative factor analysis. Since there are 39 attributes identified for the study, the ideal sample size should be 195 ( 39 X 5=195). The sample of the present study $(n=246)$ exceeds this requirement by a margin of 51 samples. The sample size of the present study also exceeds the sample size, which is used by some of the scholars those who have developed the scale. The studies used the sample sizes of 201 to purify initial instruments containing about 59 number of items (Churchill et al., 1974; Saxe and Barton, 1982). The study conducted by Parasuraman et al. (1988) used the sample size of 200, Dabholkar et al. (1996) used a sample size of 227 for both stages - scale construction and scale validation and Bahia and Nantel (2000) used a sample size of 115 for both stages.

\section{DEVELOPMENT OF THE HOSPITALQUAL THEORETICAL MODEL}

The HospitalQual theoretical model was developed based on generally accepted psychological principles of instrument design. (e.g. Nunnally, 1970; Churchill, 1979; Hinkin, 1998).

\subsection{Sampling adequacy}

Kaiser-Meyer-Olkin (KMO) is a measure of sampling adequacy statistic which indicates the proportion of variance in variables that might be caused by underlying factors. This index ranges from 0 to 1 , reaching 1 when each variable is perfectly predicted without error by the other variables. The KMO value must exceed 0.50 for both the overall fit and each individual variable, and the value above 0.8 is considered meritorious (Hair et al., 2008). The KMO measurable value for the sample adequacy of the present study is 0.860 .

Table $2 \mathrm{KMO}$ and Bartlett's Test

\begin{tabular}{|l|l|r|}
\hline Kaiser-Meyer-Olkin Measure of Sampling Adequacy. & 0.860 \\
\hline Bartlett's Test of Sphericity & Approx. Chi-Square & 1.05102 \\
\cline { 2 - 3 } & Df & 620 \\
\cline { 2 - 3 } & Sig. & .000 \\
\hline
\end{tabular}

\subsection{Exploratory Factor Analysis}

According to Hair et.al (2008), the primary purpose of factor analysis is to define the underlying structure among the variables by analyzing the structure of the interrelationships (correlations) among the large number of variables (Hair et al. 2008). The final 39 observed variables after preliminary analysis were considered as input for factor analysis. After fulfilling the prerequisites for conducting factor analysis, the next stage is to select the factor extraction method, rotational method and criteria for the number of factors to extract.

\subsection{Factor Extraction and Rotation Methods}

In factor analysis, the extraction refers to the process of obtaining underlying factors or components. Principal component factor analysis is more appropriate when data reduction is the primary concern and new meaningful underlying variables are being identified. In the present study the principal component analysis followed and adopted a Varimax rotation to reduce the data either into a smaller number of variables or set of uncorrelated measures.

\subsection{Number of Factors to Extract}

There are multiple criteria for deciding number of factors to extract. The present study followed a hybrid strategy to extract the factors by following two criteria: Kaiser's criteria (Latent root criterion) and screen test criteria which are commonly used in the social science research to extract factors.

The study used latent root methods as the first criterion to extract the factors. By this criterion the only factors having latent roots or eigenvalue greater than 1 are considered as factors.

The scree plot (Figure 1) that is derived by plotting the eigenvalues against the number of factors in their order of extraction and the shape of the resulting curve shows the cutoff point to evaluate the extracted factors.

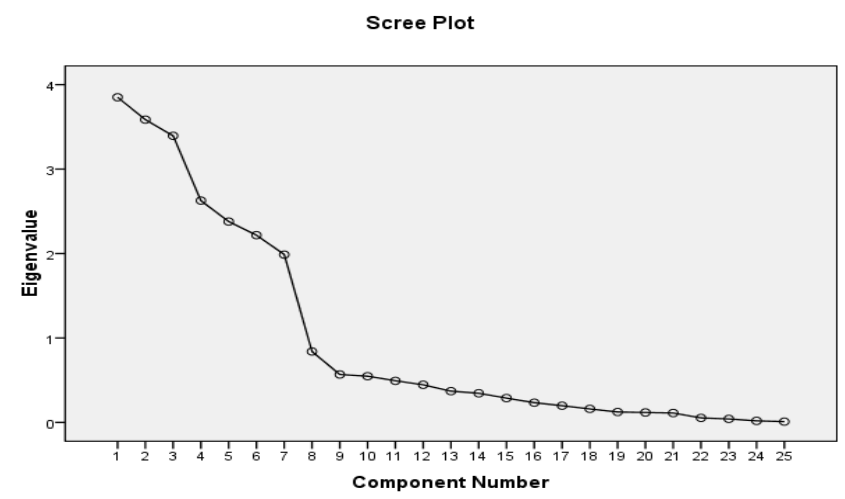

Figure 1 Screen Plot

The result of the total variance and eigenvalues of seven factors is shown in Table 3. The table presents the total variance explained by the factor analysis solution and gives an indication about the number of useful factors. The first column under "initial eigenvalues" gives the eigenvalues for all the possible factors in a decreasing order. The second column titled "extraction sums of squared loadings" gives information on factors with eigenvalues greater than 1 after factor extraction. The last part of the table, titled "rotated sums of squared loadings" gives the information on the extracted factors after rotation. The value under the column "Cumulative \%" indicates that the seven extracted factors explain $80.167 \%$ of the variance. 
Table 3 Total Variance Explained

\begin{tabular}{|c|c|c|c|c|c|c|c|c|c|}
\hline \multirow[b]{2}{*}{ Component } & \multicolumn{3}{|c|}{ Initial Eigenvalues } & \multicolumn{3}{|c|}{ Extraction Sums of Squared Loadings } & \multicolumn{3}{|c|}{ Rotation Sums of Squared Loadings } \\
\hline & Total & $\%$ of Variance & Cumulative $\%$ & Total & $\%$ of Variance & Cumulative $\%$ & Total & $\%$ of Variance & Cumulative $\%$ \\
\hline 1 & 3.851 & 15.404 & 15.404 & 3.851 & 15.404 & 15.404 & 3.492 & 13.969 & 13.969 \\
\hline 2 & 3.586 & 14.345 & 29.749 & 3.586 & 14.345 & 29.749 & 3.415 & 13.659 & 27.628 \\
\hline 3 & 3.394 & 13.578 & 43.327 & 3.394 & 13.578 & 43.327 & 3.050 & 12.200 & 39.828 \\
\hline 4 & 2.627 & 10.507 & 53.834 & 2.627 & 10.507 & 53.834 & 2.814 & 11.257 & 51.085 \\
\hline 5 & 2.378 & 9.514 & 63.348 & 2.378 & 9.514 & 63.348 & 2.527 & 10.109 & 61.195 \\
\hline 6 & 2.218 & 8.871 & 72.219 & 2.218 & 8.871 & 72.219 & 2.425 & 9.700 & 70.895 \\
\hline 7 & 1.987 & 7.948 & 80.167 & 1.987 & 7.948 & 80.167 & 2.318 & 9.272 & 80.167 \\
\hline 8 & .839 & 3.357 & 83.524 & & & & & & \\
\hline 9 & .567 & 2.270 & 85.793 & & & & & & \\
\hline 10 & .547 & 2.190 & 87.983 & & & & & & \\
\hline 11 & .492 & 1.970 & 89.952 & & & & & & \\
\hline 12 & .445 & 1.782 & 91.734 & & & & & & \\
\hline 13 & .370 & 1.479 & 93.213 & & & & & & \\
\hline 14 & .345 & 1.379 & 94.591 & & & & & & \\
\hline 15 & .288 & 1.151 & 95.742 & & & & & & \\
\hline 16 & .233 & .934 & 96.676 & & & & & & \\
\hline 17 & .198 & .790 & 97.466 & & & & & & \\
\hline 18 & .160 & .640 & 98.106 & & & & & & \\
\hline 19 & .123 & .493 & 98.599 & & & & & & \\
\hline 20 & .117 & .468 & 99.068 & & & & & & \\
\hline 21 & .111 & .444 & 99.512 & & & & & & \\
\hline 22 & .054 & .214 & 99.726 & & & & & & \\
\hline 23 & .041 & .165 & 99.891 & & & & & & \\
\hline 24 & .018 & .074 & 99.965 & & & & & & \\
\hline 25 & .009 & .035 & 100.000 & & & & & & \\
\hline
\end{tabular}

Extraction Method: Principal Component Analysis.

\subsection{Interpretation of Factor Matrix}

The study used the three criteria to determine the factor structure. They are: (1) Factor loadings more than +0.40 remained for further analysis in the study (2) items which cross load more than one factor were excluded and (3) the difference between the cross loadings should be minimum 0.20 (Hair et al., 2008). Fourteen items did not fit these criteria and were dropped from subsequent analysis. A total of 25 items grouped under seven dimensions emerged from the factor analysis as shown in the Table 4. 
Table 4 Rotated Component Matrix ${ }^{\mathrm{a}}$

\begin{tabular}{|c|c|c|c|c|c|c|c|}
\hline & \multicolumn{7}{|c|}{ Component } \\
\hline & 1 & 2 & 3 & 4 & 5 & 6 & 7 \\
\hline $\begin{array}{l}\text { MS1 } \\
\text { MS2 } \\
\text { MS3 } \\
\text { MS4 } \\
\text { NS1 } \\
\text { NS2 } \\
\text { NS3 } \\
\text { NS4 } \\
\text { SS1 } \\
\text { SS2 } \\
\text { SS3 } \\
\text { SS4 } \\
\text { AS1 } \\
\text { AS2 } \\
\text { AS3 } \\
\text { AS4 } \\
\text { PS1 } \\
\text { PS2 } \\
\text { PS3 } \\
\text { PC1 } \\
\text { PC2 } \\
\text { PC3 } \\
\text { H11 } \\
\text { HI2 } \\
\text { HI3 }\end{array}$ & $\begin{array}{l}.961 \\
.846 \\
.956 \\
.934\end{array}$ & $\begin{array}{c} \\
.931 \\
.933 \\
.785 \\
.798\end{array}$ & $\begin{array}{l}.955 \\
.913 \\
.854 \\
.952\end{array}$ & $\begin{array}{l}.770 \\
.623 \\
.872 \\
.843\end{array}$ & $\begin{array}{l}.919 \\
.977 \\
.974\end{array}$ & $\begin{array}{l}.813 \\
.914 \\
.938\end{array}$ & $\begin{array}{l}.883 \\
.932 \\
.796\end{array}$ \\
\hline
\end{tabular}

Extraction Method: Principal Component Analysis.

Rotation Method : Varimax with Kaiser Normalization.

a. Rotation converged in 6 iterations.

\subsection{Extracted Factors}

Interpreting the nature of variables and assigning meaning to the factors is an extremely important consideration in determining the number of factors to extract (Hair, et al., 2008). The process of naming the seven extracted factors is based on the nature of the variables, judgments by the experts and academicians and examination of the previous research studies. The extracted seven factors, namely: Medical Service, Nursing Services, Supportive Services, Administrative Services, Patient Safety, Patient Communication, and Hospital Infrastructure.

Table 5 Final Results of Factor Analysis

\begin{tabular}{|c|c|c|c|c|c|c|c|}
\hline Variables & 1 & 2 & 3 & 4 & 5 & 6 & 7 \\
\hline $\begin{array}{l}\text { Factor 1: Medical Service (MS) } \\
\text { MS1 Doctor was prompt in attending your need } \\
\text { MS2 Doctors listen carefully to your problem } \\
\text { MS3 You are satisfied with the time spent by doctors with you during your } \\
\text { hospitalization } \\
\text { MS4 Adequate information was provided by the doctor about treatment } \\
\text { procedures and outcomes }\end{array}$ & $\begin{array}{l}0.96 \\
0.84 \\
0.95 \\
0.93\end{array}$ & & & & & & \\
\hline $\begin{array}{l}\text { Factor 2: Nursing Services (NS) } \\
\text { NS1 Nurse was prompt in attending to your need } \\
\text { NS2 Nurse was given your prescribed medication on time } \\
\text { NS3 Nurse was courteous } \\
\text { NS4 Nurse was helpful }\end{array}$ & & $\begin{array}{l}0.93 \\
0.93 \\
0.78 \\
0.79\end{array}$ & & & & & \\
\hline
\end{tabular}


Table 5 Final Results of Factor Analysis (Contd.)

\begin{tabular}{|c|c|c|c|c|c|}
\hline $\begin{array}{l}\text { Factor 3: Supportive Services (SS) } \\
\text { SS1 The hospital provides Diagnostics services with less waiting time } \\
\text { SS2 Required Medicines are available in the pharmacy } \\
\text { SS3 Hospital provided good food ( nutritious, hygiene and timelines) } \\
\text { SS4 Housekeeping staff maintains cleanliness in the ward/room }\end{array}$ & $\begin{array}{l}0.95 \\
0.91 \\
0.85 \\
0.95\end{array}$ & & & & \\
\hline $\begin{array}{l}\text { Factor 4: Administrative Services (AS) } \\
\text { AS1 Hospital admission processes was simple } \\
\text { AS2 Proper facilities provided in the hospital for the attendants } \\
\text { AS3 Hospital administration responded immediately to solve your } \\
\text { problems } \\
\text { AS4 Discharge process was completed without delay }\end{array}$ & & $\begin{array}{l}0.77 \\
0.62 \\
0.87 \\
0.84\end{array}$ & & & \\
\hline $\begin{array}{l}\text { Factor 5: Patient Safety (PS) } \\
\text { PS1 Adequacy of hygienic care and procedures (e.g. hand wash, wearing } \\
\text { gloves) followed by the hospital staff } \\
\text { PS2 The hospital provides proper measures (e.g. bed with side handrails } \\
\text { in aisles, ramps designed for wheelchairs) to reduce the risk of patient } \\
\text { harm resulting from falls } \\
\text { PS3 You had not suffered from hospital infection after } 24 \text { hours of } \\
\text { admission }\end{array}$ & & & $\begin{array}{l}0.91 \\
0.97 \\
0.97\end{array}$ & & \\
\hline $\begin{array}{l}\text { Factor 6: Patient Communication (PC) } \\
\text { C1 Adequate information was provided by the staff } \\
\text { C2 There is a clarity in staff communication } \\
\text { C3 During admission you and /or your family members were given proper } \\
\text { counseling to make informed decisions }\end{array}$ & & & & $\begin{array}{l}0.81 \\
0.91 \\
0.93\end{array}$ & \\
\hline $\begin{array}{l}\text { Factor 7: Hospital Infrastructure (HI) } \\
\text { I1 The physical facilities of hospital are visually appealing } \\
\text { I2 The hospital have necessary up-to-date equipment } \\
\text { I3 The hospital staff are well dressed and appear neat }\end{array}$ & & & & & $\begin{array}{l}0.88 \\
0.93 \\
0.79\end{array}$ \\
\hline
\end{tabular}

\subsection{Reliability of HospitalQual Theoretical Model}

Reliability is an assessment of the degree of consistency between multiple measurements of a variable (Hair et al., 2008). The Cronbach's alpha coefficient is the most widely used measure to assess the consistency of the entire scale and it could be considered reliable with a lower limit of 0.70 although it decreases to 0.60 in exploratory research (Cronbach, 1951 and Straub et al., 2004). The reliable measures of the seven extracted critical factors of HospitalQual are shown in Table 6. Using the SPSS reliability program, an internal consistency analysis was performed separately for the items of each critical factor of inpatient' service quality. The seven factors have high Cronbach's alpha values as shown in the Table 6. That indicates all of these factors contribute the largest part of the variance of the HospitalQual theoretical model.

\subsection{Validity of HospitalQual Theoretical Model}

The validity of a measure refers to the extent to which it measures what is intended to be measured. Given that the questionnaire had been appropriately designed through a comprehensive review of relevant literature, in-depth interviews and then fined-tuned based on the suggestions from various experts, content (face) validity of the instrument was ensured (Kaplan \& Saccuzzo, 1993).

The ANOVA test was administered to validate the scale. As shown in the Table 7, the results of the theoretical model show that all the dimensions of inpatient service quality, statistically significant and these dimensions are significantly explaining the model.

Table 6 Reliability Analysis of HospitalQual's Dimensions

\begin{tabular}{|c|l|c|}
\hline S.No & \multicolumn{1}{|c|}{ Dimensions of HospitalQual } & $\begin{array}{c}\text { Cronbach's } \\
\text { Alpha }\end{array}$ \\
\hline 1 & Medical Service & .953 \\
\hline 2 & Nursing Services & .895 \\
\hline 3 & Supportive Services & .943 \\
\hline 4 & Administratvie Services & .826 \\
\hline 5 & Patient Safety & .970 \\
\hline 6 & Patient Communication & .877 \\
\hline 7 & Hospital Infrastruture & .759 \\
\hline
\end{tabular}


Table 7. Results of ANOVA

\section{ANOVA}

\begin{tabular}{|ll|r|r|r|r|r|}
\hline & \multicolumn{1}{c|}{$\begin{array}{c}\text { Sum of } \\
\text { Squares }\end{array}$} & df & Mean Square & F & Sig \\
\hline Between People & & 655.431 & 823 & .796 & & \\
Within People & Between Items & 1202.316 & 6 & 200.386 & 249.008 & .000 \\
& Residual & 3973.793 & 4938 & .805 & & \\
Total & 5176.109 & 4944 & 1.047 & & \\
\hline
\end{tabular}

Grand Mean $=3.3968$

\section{MULTIPLE REGRESSION ANALYSIS}

The multiple regression was used to determine the total effect of the seven factors (dimensions) on the inpatients' service quality (or how well the seven dimensions predicted inpatient service quality) and to assess the relative importance of the individual dimensions. For the regression model the seven extracted factors were considered as the independent variables and the level of overall inpatients' service quality as the dependent variable. The summated scales of each factor were calculated by averaging all values of scale items within the particular factor (Hair et al., 2008). A multiple regression analysis was subsequently conducted to test the hypotheses from H1 to H7. The coefficient of determination " $\mathrm{R}$ " is found to be high enough. The adjusted $\mathrm{R} 2$ was $0.86(\mathrm{p}<0.001)$ yielding seven dimensions contributing significantly towards explaining the variance in the level of overall inpatient's service quality in hospitals.

\subsection{Results of Hypotheses Testing}

The proposed hypothesis are tested using multiple regression analysis as shown in the Table 8. The model assesses the effect of Medical service, Nursing services, supportive services, administrative services, Patient safety, Patient communication, and Hospital Infrastructure on the overall inpatient service quality of hospitals.

The results of regression analysis shown in the Table $\mathbf{8}$ indicates that all the factors have a significant effect on overall inpatient service quality with positive standardized coefficient values. Hence, the proposed seven hypotheses significantly affect the level of inpatient service quality is supported. The summary of hypotheses results is shown in the Table 9.

Table 8 Regression Coefficients - Effect of Seven Factors on Inpatient Service Quality Coefficients ${ }^{\mathrm{a}}$

\begin{tabular}{|c|c|c|c|c|c|c|c|}
\hline & \multirow[b]{2}{*}{ Model } & \multicolumn{2}{|c|}{ Unstandardized Coefficients } & \multirow{2}{*}{$\begin{array}{c}\begin{array}{c}\text { Standardized } \\
\text { Coefficients }\end{array} \\
\text { Beta }\end{array}$} & \multirow[b]{2}{*}{$t$} & \multirow[b]{2}{*}{ Sig. } & \multirow[t]{2}{*}{ R Square } \\
\hline & & B & Std. Error & & & & \\
\hline \multirow[t]{8}{*}{1} & (Constant) & 3.048 & .310 & & 9.844 & .000 & \\
\hline & MS & .062 & .029 & .075 & 2.145 & .032 & \\
\hline & NS & .66 & .029 & .079 & 2.242 & .025 & \\
\hline & SS & .082 & .029 & .099 & 2.836 & .005 & .86 \\
\hline & AS & .078 & .036 & .077 & 2.197 & .028 & \\
\hline & PS & .059 & .038 & .055 & 2.246 & .023 & \\
\hline & PC & .068 & .032 & .074 & 2.101 & .036 & \\
\hline & $\mathrm{HI}$ & .045 & .038 & .041 & 9.168 & .000 & \\
\hline
\end{tabular}

a. Dependent Variable: IPSQ

Table 9: Results of Hypothesis Testing

\begin{tabular}{|l|c|c|c|}
\hline \multicolumn{1}{|c|}{ Hypothesis } & t value & P value & Results \\
\hline $\mathrm{H}_{1}:$ Medical Service has a significant effect on inpatient service quality & 2.145 & 0.032 & Accepted \\
\hline $\mathrm{H}_{2}:$ Nursing Services have a significant effect on inpatient service quality & 2.242 & 0.025 & Accepted \\
\hline $\mathrm{H}_{3}:$ Supportive Services have a significant effect on inpatient service quality & 2.836 & 0.005 & Accepted \\
\hline $\mathrm{H}_{4}:$ Administrative Services have a significant on inpatient service quality & 2.197 & 0.028 & Accepted \\
\hline $\mathrm{H}_{5}:$ Patient Safety has a significant effect on inpatient service quality & 2.246 & 0.023 & Accepted \\
\hline $\mathrm{H}_{6}:$ Patient Communication has a significant effect on inpatient service quality & 2.101 & 0.036 & Accepted \\
\hline $\mathrm{H}_{7}:$ Hospital Infrastructure has a significant effect on inpatient service quality & 9.169 & 0.000 & Accepted \\
\hline
\end{tabular}




\section{CONCLUSION}

The present study explains the process of developing the HospitalQual theoretical model. The exploratory factor analysis resulted in seven critical factors of perceived inpatient service quality in the hospital. Multiple regression analysis was used to test the hypotheses about the significant effect of extracting critical factors i.e. medical service, nursing service, support services, administrative services, patient safety, patient communication, and hospital infrastructure on overall inpatient service quality in the hospital. The test proved that all the factors have a significant effect on inpatient service quality. In addition, the supportive services are found to be the most important factor to predict the overall inpatient service quality, followed by nursing services, administrative services, medical services, patient communication, patient safety, and hospital infrastructure.

The application of HospitalQual would help to identify the gaps in each of the dimensions over a period of time and enable hospital administrators to monitor, control, and improve the inpatient service quality. Thus, the HospitalQual will help in pinpointing the areas of managerial attention and action to improve inpatient service quality in hospitals. The present study has limitations of generalizability of the research findings across hospitals in other parts of the state and the country. However, the HospitalQual theoretical model needs to be validated for the generalization with advanced statistical tools like Structure Equation Modeling (SEM). In essence, the study highlighted the critical factors of service quality and demonstrated in the context of inpatient hospital services.

\section{REFERENCES}

Aagja, J. P., and Garg, R. (2010), Measuring perceived service quality for public hospitals (PubHosQual) in the Indian context, International Journal of Pharmaceutical and Healthcare Marketing 4 (1), pp. 60-83.

Andaleeb, S. S. (1998), Determinants of customer satisfaction with hospitals: a managerial model, International Journal of Health Care Quality Assurance 11 (6), pp. 181-187.

Arasli, H., Ekiz, E. H., and Katircioglu, S. T. (2008), Gearing service quality into public and private hospitals in small islands: empirical evidence from Cyprus, International Journal of Health Care Quality Assurance 21 (1), pp. 8-23.

Bahia, K., and Nantel, J. (2000), A reliable and valid measurement scale for the perceived service quality of banks, International Journal of Bank Marketing 18 (2), pp. 84-91.

Baker, R. (1990), Development of a questionnaire to assess patients' satisfaction with consultations in general practice, The British Journal of General Practice 40 (341), pp. 487 490

Berry, L. L., Zeithaml, V. A., and Parasuraman, A. (1985), Quality counts in services, too, Business Horizons 28 (3), pp. 44-52.

Camilleri, D., and O'Callaghan, M. (1998), Comparing public and private hospital care service quality, International Journal of Health Care Quality Assurance 11 (4), pp. 127-133.

Chowdhary, N., and Prakash, M. (2007), Prioritizing service quality dimensions, Managing Service Quality 17 (5), pp. 493-509.

Churchill Jr, G. A., Ford, N. M., and Walker Jr, O. C. (1974), Measuring the job satisfaction of industrial salesmen, Journal of Marketing Research, pp. 254-260.
Cronbach, L. J. (1951), Coefficient alpha and the internal structure of tests, Psychometrika 16 (3), pp. 297-334.

Dabholkar, P. A., Thorpe, D. I., and Rentz, J. O. (1995), A measure of service quality for retail stores: scale development and validation, Journal of the Academy of Marketing Science 24 (1), pp. 3-16.

Dagger, T. S., Sweeney, J. C., and Johnson, L. W. (2007), A hierarchical model of health service quality scale development and investigation of an integrated model, Journal of Service Research 10 (2), pp. 123-142.

Fitzpatrick, R. (1991), Surveys of patients satisfaction: I-Important general considerations, BMJ: British Medical Journal 302 (6781), pp. 887-889.

Gefen, D., and Straub, D. (2005), A practical guide to factorial validity using PLS-Graph: Tutorial and annotated example, Communications of the Association for Information Systems $16(1)$, pp. 5.

Grönroos, C. (1984), A service quality model and its marketing implications, European Journal of marketing 18 (4), pp. 3644

Hair, J. F. Jr., Anderson, R. E., Tatham, R. L. and Black, W. C. (2008), Multivariate data analysis. New Jersey: Prentice Hall.

Hasin, M. A. A., Seeluangsawat, R., and Shareef, M. A. (2001), Statistical measures of customer satisfaction for health care quality assurance: a case study, International Journal of Health Care Quality Assurance 14 (1), pp. 6-14.

Hinkin, T. R. (1998), A brief tutorial on the development of measures for use in survey questionnaires, Organizational Research Methods 1 (1), pp. 104-121.

Jabnoun, N., and Chaker, M. (2003), Comparing the quality of private and public hospitals, Managing Service Quality 13 (4), pp. 290-299.

John, J. (1989), Quality in health care service consumption: what are the structural dimensions. In Hawes, J.M., Thanopoulos, J. (Eds.), Developments in Marketing Science, Academy of Marketing Science 12, pp. 518-521. Orlando, FL.

Johnston, R. (1995), The zone of tolerance: exploring the relationship between service transactions and satisfaction with the overall service, International Journal of Service Industry Management 6 (2), pp. 46-61.

Jun, M., Peterson, R. T., and Zsidisin, G. A. (1998), The identification and measurement of quality dimensions in health care: focus group interview results, Health Care Management Review 23 (4), pp. 81-96.

Kaplan, R.M., and Saccuzzo, D.P. (1993), Psychologicaltesting: Principles, applications and issues $\left(3^{\mathrm{rd}}\right.$ Ed.). Paci®cGrove, CA: Brooks/Cole.

Karatepe, O. M., Yavas, U., and Babakus, E. (2005), Measuring service quality of banks: scale development and validation, Journal of Retailing and Consumer Services 12 (5), pp. 373383.

Kettinger, W. J., Lee, C. C., and Lee, S. (1995), Global Measures of Information Service Quality: A Cross-National Study, Decision Sciences 26 (5), pp. 569-588.

Kritchanchai, D. (2012), A Framework for Healthcare Supply Chain Improvement in Thailand, Operations and Supply Chain Management 5 (2), pp. 103-113.

Lehtinen, U., and J.R. Lehtinen (1985), Service Quality: a Study of Quality Dimensions, paper read at the Second World Marketing Congress, University of Stirling, Scotland.

Lim, P. C., and Tang, N. K. (2000), A study of patients' expectations and satisfaction in Singapore hospitals, International Journal of Health Care Quality Assurance 13 (7), pp. 290-299.

Nunnally, Jum C. (1970). Introduction to Psychological Measurement. New York: McGraw-HiI I.

Padma, P., Rajendran, C., and Lokachari, P. S. (2010), Service quality and its impact on customer satisfaction in Indian 
hospitals: Perspectives of patients and their attendants, Benchmarking: An International Journal 17 (6), pp. 807-841.

Parasuraman, A., V.A. Zeithaml and L.L. Berry (1988), SERVQUAL: a Multiple-Item Scale for Measuring Consumer Perceptions of Service Quality, Journal of Retailing 64 (1), pp. 12-40.

Parasuraman, A., Zeithaml, V.A. and Berry, L.L. (1985), A conceptual model of service quality and implications for future research, Journal of Marketing 49, pp. 41-50.

Reidenbach, R. E., and Sandifer-Smallwood, B. (1990), Exploring perceptions of hospital operations by a modified SERVQUAL approach, Journal of Health Care Marketing $10(4)$, pp. 47-55.

Saxe, R., and Weitz, B. A. (1982), The SOCO scale: a measure of the customer orientation of salespeople, Journal of marketing research, pp. 343-351.

Thompson, A.G.H. (1983), The measurement of patients' perceptions of the quality of hospital care. Unpublished doctoral thesis, UMIST, University of Manchester, Manchester.
Tomes, A. E., and Ng, S. C. P. (1995), Service quality in hospital care: the development of an in-patient questionnaire, International Journal of Healthcare Quality Assurance 8 (3), pp. 25-33.

Tucker, J. L., and Adams, S. R. (2001), Incorporating patients' assessments of satisfaction and quality: an integrative model of patients' evaluations of their care, Managing Service Quality 11 (4), pp. 272-287.

Walters, D., and Jones, P. (2001), Value and value chains in healthcare: a quality management perspective, The TQM Magazine 13 (5), pp. 319-335.

Zakaria, H., Zailani, S., and Fernando, Y. (2010), Moderating role of logistics information technology on the logistics relationships and logistics service quality, Operations and Supply Chain Management 3 (3), pp. 134-147.

Zyzanski, S. J., Hulka, B. S., and Cassel, J. C. (1974), Scale for the measurement of" satisfaction with medical care: modifications in content, format and scoring, Medical Care, pp. 611-620.

Ramaiah Itumalla is a full time research scholar at School of Management Studies, University of Hyderabad, India. He has published more than 16 articles in National and International Journals apart from presenting several papers at national and international conferences in Singapore and Thailand. His research interest includes Healthcare Service Quality, Public Heath, Managed Insurance and Hospital Management.

Dr. G.V.R.K Acharylu is Associate Professor and Coordinator, MBA Healthcare and Hospital Management at the School of Management Studies, University of Hyderabad, India. He has published around 50 research papers in national and international journals and presented several papers at international conferences in USA, UAE, Australia, Singapore, Malaysia and Thailand. He has authored books viz. Supply Chain Management in Healthcare Industry, Emerging Trends in Healthcare Industry, Pharmacy Administration, Research Methodology \& Statistical Tools, Marketing Research, Supply Chain Management and Strategic Quality Management. His research areas include Healthcare Management, Operations, Supply chain Management and Theory of Constraints.

Prof. B. Raja Shekhar is an engineer and a manager by education, a teacher and academic administrator by choice, a trainer and scholar by profession at School of Management Studies, University of Hyderabad. He has published more than 50 research papers in national and international journals and presented several papers at international conferences in UAE, Singapore and Thailand. He has authored several books and he is also a well known recourse person in India for research methodology. His primary areas of interests include Research Methodology, Quantitative Techniques, Operations Management and Research, Quality Management, Supply Chain Management, Project Management and Consumer Protection. 